\title{
Mateusz Kusio
}

Humboldt-Universität zu Berlin ORCID: 0000-0003-3915-7323

mateusz.kusio@hu-berlin.de

\section{KOLORYSTYKA BIBLIJNA \\ I METAFORY UCIELEŚNIONE \\ NA PRZYKŁADZIE CZERNI \\ W PIEŚNI NAD PIEŚNIAMI 1,5-6 \\ I JEJ WCZESNEJ RECEPCJI}

DOI: 10.52097/acapress.9788362475810.145-165

\section{Słowa kluczowe: Streszczenie}

Pieśń nad Artykuł ma na celu ukazanie znaczenia czerni w kon-

Pieśniami, tekście Pieśni nad Pieśniami I,5-6 oraz jej wczesnej targum, recepcji. Przeistacza się ona w oczach późniejszych midrasz, czerń, interpretatorów z opisu dosłownego w metaforę uciele-

Orygenes śnioną wyrażającą prawdy religijne. Dosłowność samego z Aleksandrii, wersetu biblijnego jest dowiedziona przez jego analize metafora filologiczną. Za reprezentatywne przykłady jego recepcji wzięte są: targum i midrasz do Pieśni nad Pieśniami oraz komentarz i homilie Orygenesa $z$ Aleksandrii. Ich lektura pozwala wykazać, że traktują oni czerń i wygląd oblubienicy z Pieśni nad Pieśniami jako metaforę niewiedzy, grzechu, odrzucenia przez Boga czy też niskiego stanu, jednocześnie wchodząc ze sobą w dialog egzegetyczny. 


\section{Keywords: Abstract}

Song of Songs, The article aims to present the meaning of black in Targum, Song of Songs I:5-6 and its early reception, arguing at

Midrash, the same time that in the eyes of the later interpreters, black, Origen the colour transforms from a literal description into of Alexandria, an embodied metaphor expressing truths of religious metaphor nature. The literal nature of the Biblical verse is proven by the means of philological close reading. Its reception is exemplified by the Targum and the Midrash to the Song of Songs and, on the other hand, Origen's commentary and homilies. By reading them it can be shown that, while remaining in an exegetical dialogue, they take the colour black and the Bride's appearance within the Song of Songs as being metaphors for ignorance, sin, rejection by God, or low social stature.

\section{Wstęp}

B iblijna księga Pieśni nad Pieśniami (hebr. szir haszszirim ${ }^{\mathrm{T}}$ ) jest B poematem miłosnym, skonstruowanym na zasadzie dialogu między dwojgiem kochanków. Pierwszy werset księgi przypisuje jej autorstwo królowi Salomonowi (stąd też znana jest jako Pieśń Salomonowa), co oznaczałoby, że została spisana w połowie $\mathrm{X}$ wieku p.n.e. Większość współczesnych komentatorów traktuje jednak wzmiankę o Salomonie w Pnp I,I jako anachroniczną czy też pseudograficzną, zwracając równocześnie uwagę na zapożyczenia leksykalne i składniowe $z$ języków względem hebrajskiego ościennych: aramejskiego (np. użycie prefiksu sze-zamiast zaimka względnego aszer w Pnp I,7; 4,2; 5,2, 8), perskiego (paredes, „ogród” w 4,I3) oraz greckiego (apirejon, „tron, lektyka” w 3,9). Ponieważ kontakt $z$ tymi językami wzmógł się w okresie obcej dominacji nad Palestyną, trwającym od wygnania babilońskiego

Transkrypcja zapisu hebrajskiego i aramejskiego na alfabet łaciński w całym artykule została dokonana w oparciu o zasady przedstawione przez Wronkę (2004). 
(586 rok p.n.e.), kompozycję Pieśni nad Pieśniami umiejscawia się $z$ przyczynek lingwistycznych w okresie od VI do III wieku p.n.e. Swoista ahistoryczność tekstu, tj. brak wyraźnych odniesień do sytuacji politycznej czasu jego powstania, czyni nadzieje na dokładniejsze umieszczenie go w czasie płonnymi (Murphy, I990, s. 3-5; Zakovitch, 2004, s. 64-66).

Pieśń nad Pieśniami rozpoczyna się pieśnią oblubienicy, zwracającej się do ukochanego, jak i do swoich druhen. Pierwsze sześć wersetów księgi warto przytoczyć in extenso.

I Pieśń pieśni, która jest Salomona.

2 Pocałuj mnie jednym z pocałunków twoich ust, bowiem lepsza jest twoja miłość od wina.

3 Woń twoich balsamów jest miła, Twoje imię balsamem rozlanym, to dlatego kochają cię panny.

4 Zabierz mnie za sobą, pobiegnijmy! Król wprowadził mnie do swoich komnat. Będziemy się tobą cieszyć i radować. Wspomnimy Twoją miłość lepiej niż wino. Słusznie cię kochają!

5 Czarna jestem, lecz piękna, córki Jeruzalem, jak namioty Kedaru, jak zasłony Salomona.

6 Nie patrzcie na mnie, że jestem sczerniała, że opaliło mnie słońce. Synowie mojej matki zapłonęli gniewem wobec mnie - postawili mnie na straży swoich winnic, a mojej winnicy nie ustrzegłam².

Punktem wyjścia poniższych rozważań będzie jeden szczegół tekstu, a mianowicie fakt, że mówiąca opisuje samą siebie jako czarną (Pnp I,5) czy też sczerniałą (Pnp I,6). Głównym postulatem będzie, że barwa ta w samym tekście biblijnym ma znaczenie dosłowne, zaś w jego starożytnej recepcji staje się metaforą ucieleśnioną, w ramach której interpretatorzy używali zmysłowego doświadczenia czerni jako swoistej reprezentacji pojęć bardziej abstrakcyjnych, takich jak grzech, niewiedza czy odrzucenie przez Boga. Pierwsza część artykułu poświęcona będzie stosowanemu aparatowi pojęciowemu i jego użyteczności w odniesieniu do

2 Tłumaczenie autora na podstawie tekstu hebrajskiego z Biblia Hebraica Stuttgartensia. 
studiów biblistycznych. Następnie analizie filologicznej poddane zostaną dwa wyżej wspomniane wersety. Przykłady żydowskiej i chrześcijańskiej egzegezy Pnp I,5-6 - kolejno: targum do Pieśni nad Pieśniami, midrasz Szir Haszirim Rabba, komentarz i homilie do Pieśni nad Pieśniami autorstwa Orygenesa z Aleksandrii - zostaną omówione w części trzeciej.

\section{Aparat pojęciowy}

Twierdzenie, że czerń w Pnp I,5-6 staje się stopniowo metaforą ucieleśnioną, używa pojęć przynależnych naukom kognitywistycznym, które należy zdefiniować i dowieść ich stosowalności i użyteczności w biblistyce. Kluczowym spośród nich jest „metafora ucieleśniona”, wymagająca starannego objaśnienia. Metafora jako taka spotyka się $z$ żywotnym zainteresowaniem kognitywistów i lingwistów za sprawą pionierskich w tym zakresie badań Lakoffa i Johnsona (1980), które wskazały na kluczową rolę metafor w procesach poznawczych. Metafory w ujęciu teorii kognitywnej nie pełnią wyłącznie roli retorycznej, ale stanowią narzędzia, za pomocą których umysł ujmuje pojęcia abstrakcyjne, przynależne tzw. domenie docelowej (czas, sympatia, dyskusja). Wyrażenia metaforyczne pozwalają rzutować te pojęcia na zjawiska empirycznie dostępne, czyli domenę źródłową (pieniądze, ciepło, wojna). Fakt, iż zjawiska przynależące do domeny źródłowej doświadczane są zazwyczaj zmysłowo czy też cieleśnie, ma dla kognitywnej teorii metafor znaczenie fundamentalne (Johnson, 1987; Geeraerts, 2009, s. 204; Gibbs, 20I7, s. 23-30). Grady (I999) przekonująco stwierdza, że podstawowe doświadczenia fizyczne i ucieleśnione są źródłem tzw. metafor podstawowych (primary metaphors).

Nauki kognitywne angażują się również coraz bardziej w badania nad embodied cognition, "poznaniem ucieleśnionym”. Żeby uchwycić istotę tego pojęcia, posłużę się spostrzeżeniami Lawrencéa Barsalou (I999), przedstawionymi w kluczowym w tym obszarze artykule o symbolach percepcyjnych (perceptual symbols). Według Barsalou o ucieleśnieniu mowa może być wtedy, kiedy reprezentacje umysłowe, które on nazywa symbolami, powiązane 
są z symulacjami zmysłowymi. Dla przykładu: kiedy myślę o owocu kiwi, równocześnie wyobrażam sobie zapewne jego kwaśny smak, kolor jego skórki i miąższu oraz fakturę pokrywających go włosków, a tym samym ucieleśniam swój proces poznawczy poprzez odtworzenie pewnych konkretnych wrażeń zmysłowych. Reasumując, należy stwierdzić, że metafora ucieleśniona będzie rozumiana jako ta, w której na pojęcia $z$ domeny abstrakcyjnej rzutowane są symulowane doznania zmysłowe. Metafora „niewiedza to ciemność" będzie ucieleśniona, jeżeli jej użyciu towarzyszyć będzie odtworzenie wzrokowego doznania ciemności, jak również doznań z nim powiązanych, np. dezorientacji.

Należy nadmienić, że rozważania będą kontynuowane przy założeniu, że metafory faktycznie mogą być w ścisłym sensie ucieleśnione i jako takie uczestniczyć w procesach kognitywnych. Założenie to spotyka się z krytyką. Sam Barsalou (I999, s. 600) stwierdza, że symbole percepcyjne mogą oddawać pojęcia abstrakcyjne nie metaforycznie, a bezpośrednio (np. pojęcie gniewu może być reprezentowane przez symbole takie jak doświadczenia nieosiągnięcia celów oraz reakcje afektywne i behawioralne). Co więcej, Casasanto i Gijssels (2015) wskazują, że większość metafor, które inni badacze skłonni są poczytywać za ucieleśnione, nie aktywuje w mózgu obszarów właściwych danym modalnościom zmysłowym, a więc nie wiąże się z symulacjami percepcyjnymi. Odpowiadając na ich argumenty, Gibbs (2017, s. 206-207) stwier$\mathrm{d} z a$, że wiele metafor opartych na doświadczeniu ucieleśnionym ma charakter polisensoryczny, np. balans może odnosić się do ruchu i fizycznej równowagi, a zarazem do dźwięku („balans głośników”) oraz do smaku („zbalansowany smak zupy”). Tym samym fakt, że metafory takie nie aktywują konkretnych modalności zmysłowych na poziomie neurologicznym nie jest jeszcze wystarczającym dowodem, że nie są one w ogóle ucieleśnione.

Jak i w jakim stopniu pojęcie metafory ucieleśnionej może być zastosowane do tekstu starożytnego, jakim jest Pieśń nad Pieśniami, i jego późniejszego - również, trzeba nadmienić, zapośredniczonego przez teksty - odbioru? Oczywiście, niemożliwością jest powiedzieć cokolwiek o procesach poznawczych czy tym bardziej mózgowych któregokolwiek $z$ autorów, o których będzie mowa - 
nie sposób więc bezspornie stwierdzić, czy używane przez nich metafory wiązały się $z$ takimi czy innymi symulacjami zmysłowymi. Nie jest to jednak nieprawdopodobne, bowiem Pieśń nad Pieśniami jest tekstem par excellence ewokatywnym i piktorialnym, niejako zapraszającym czytelników i czytelniczki do wstąpienia w swój krajobraz sensoryczny. Jeżeli lekturze jakiegokolwiek tekstu towarzyszy pobudzenie zmysłów, to tekstem tym jest właśnie biblijna Pieśń nad Pieśniami.

Teoria metafor kognitywnych odbija się coraz szerszym echem w biblistyce, oferując nowe sposoby odczytywania tekstów biblijnych i pokrewnych oraz zawartych w nich obrazów i metafor. Liczba studiów tropiących i analizujących kompleksy metafor poznawczych w Biblii hebrajskiej, Nowym Testamencie i tekstach pozakanonicznych stale przyrasta (zob. np. Howe, 2006; Jindo, 20Io; Hogan, 20I ; Tilford, 20I7). Pieśń nad Pieśniami, jako tekst w warstwie literackiej i znaczeniowej unikatowy w kanonie biblijnym, również została poddana badaniom czerpiącym $z$ kognitywistycznego namysłu nad pojęciem metafory (Gault, 20I9). Miller (20I2, s. II8) stwierdza, że "metafory dzierżą klucz do estetyki Pieśni”. Niniejsze studium - jakkolwiek skromne w swoim zakresie - kontynuuje kognitywistyczne podejście do metafor Pieśni nad Pieśniami, a jednocześnie wpisuje je w historię recepcji tekstu biblijnego, mając na celu wskazanie, że to, co pierwotnie dosłowne, może w egzegezie późniejszej stać się właśnie metaforą kognitywną.

\section{Pieśń nad Pieśniami 1,5-6}

Należy teraz skupić się na samym tekście wersetów piątego i szóstego z pierwszego rozdziału Pieśni nad Pieśniami w celu objaśnienia ich warstwy językowej i semantycznej. W wersecie piątym oblubienica zwraca się do swoich druhen - „córek jerozolimskich" - opisując poetycko swój wygląd. Określa się jako szechora, „czarna”, wenawa, ,i/lecz piękna”. Sens cząstki $w^{e}$, najbardziej podstawowego spójnika hebrajskiego, w tym wersecie jest przedmiotem debaty egzegetycznej i translatorskiej, nie jest 
bowiem jasne, czy wprowadza ona koniunkcję (czerń i piękno są ze sobą w zgodzie) czy też opozycję (mówiąca jest piękna pomimo koloru swojej skóry). Jeżeli założy się, że między wersetami piątym i szóstym, gdzie sama mówiąca wstydzi się swojej karnacji, zachodzi ciągłość, to słowa te należałoby - tak jak to zostało uczynione powyżej - przełożyć jako ,jestem czarna, lecz piękna”, podążając tym samym za intuicją większości badaczy (Hostetter, I996; Zakovitch, 2004, s. II7; Barbiero, 20II, s. 60; Fishbane, 2015, s. 34; Gault, 2019, s. 67-69; por. jednak Dobbs-Allsopp, 2006) ${ }^{3}$.

$\mathrm{W}$ wersecie piątym następują potem dwa porównania, ,jak namioty Kedaru, jak zasłony Salomona". W pierwszym z nich mowa o namiotach północnoarabskiego związku plemiennego $z$ połowy I tysiąclecia p.n.e., wspominanego też m.in. w Ps I20:5; Iz 2I,I6. (Kedar był też według $\mathrm{Rd} z$ 25,I3 synem Iszmaela i wnukiem Abrahama, zaś samo imię pochodzi prawdopodobnie od hebrajskiego czasownika qadar, „być czarnym”.) Drugie porównanie wiąże wygląd mówiącej $z$ tkaninami świątyni Salomona w Jerozolimie. Niektórzy współcześni komentatorzy i tłumacze, w tym polska Biblia Tysiaclecia, odrzucają tradycyjną wokalizację zapisu spółgłoskowego jako $s z^{e} l o m o$, ,,Salomona”, proponując za to szal $m a$, "Szalmy”, nazwy oznaczającej bliżej niezidentyfikowane plemię arabskie i poświadczonej jedynie w targumach. Użycie tej nazwy własnej wzmacniałoby paralelizm między dwoma częściami wersetu, które miałyby taką samą strukturę, tj. ,jak + [namioty/ zasłony] + [nazwa plemienna]". Należy tę interpretację mimo wszystko odrzucić, bowiem szłaby ona w poprzek długiej tradycji interpretacyjnej, nie znajdując również potwierdzenia w starożytnych tłumaczeniach (Gault, 20I9, s. 7I-72). Werset jako całość można rozumieć jako kunsztowne skrzyżowanie porównań (por. Barbiero, 20II, s. 6I; Fishbane, 20I5, s. 35):

3 Nie ma tu miejsca na podjęcie, badawczo ciekawej i społecznie istotnej, problematyki rasy i koloru skóry w Pieśni nad Pieśniami. W rozważanym tu wersetach kolor skóry mówiącej jest wynikiem opalenizny i nie należy go rozumieć jako wskaźnika rasowego; por. niedawne rozważania Ogden Bellis (202I). Nie oznacza to jednak, że księga jako całość nie daje autentycznego asumptu do krytycznych rozważań na te tematy. Wabyanga (2015) proponuje afrykańskie spojrzenie postkolonialne na Pnp I,5-7. 
"Czarna jestem,
$\uparrow$ córki jerozolimskie, $\downarrow$
jak namioty Kedaru,

Werset szósty wyjaśnia kolor skóry oblubienicy, która chce, żeby odwrócono od niej wzrok, bowiem jest $s z^{e}$ char choret, „sczerniała”, „smagła” lub też „pociemniała” (słowo pochodne, możliwie zdrobnienie, od $s z^{e}$ chora w Pnp I,5), co wynika z jej pracy w winnicy swoich braci („synów mojej matki”, możliwie braci przyrodnich), gdzie opaliło ją słońce. Mówiąca nie wyjaśnia, czy gniew jej braci (użyty tu czasownik nicharu jest pochodną formy podstawowej charar, „płonąc", co współgra z resztą sytuacji lirycznej) jest wynikiem, czy też przyczyną tego, że zajmowała się cudzą, a nie własną winnicą.

Tekst Pnp I,5-6 na swoim podstawowym poziomie metaforyczny nie jest - wprost przeciwnie, traktuje doświadczenie karnacji i czerni jak najbardziej fizycznie i poważnie, starając się zdjąć ciążące na nim odium. Komentatorzy wskazują jednak, że użycie obrazu winnicy w wersecie szóstym może wpisywać się w typowe dla Pieśni nad Pieśniami rozumienie ciała jako krajobrazu, które Gault (20I9, s. 4I-42, 60) klasyfikuje jako kluczową metaforę konceptualną całego tekstu. Jeżeli więc winnicę w słowach oblubienicy pojmie się jako jej ciało, możliwy podtekst seksualny staje się bardziej wyrazisty. Badacze sugerują, że nieupilnowanie winnicy może być eufemizmem na aktywność seksualną czy też utratę dziewictwa (Pope, I977, s. 326; Garbini, I992, s. I88). Taka lektura Pnp I,6 jest jednak niesatysfakcjonująca $z$ dwóch różnych powodów: po pierwsze, jeżeli pozostawienie własnej winnicy przez mówiącą oznaczałoby stosunek z jej ukochanym, jak należałoby rozumieć pilnowanie przez nią winnicy synów jej matki? Rozciągnięcie metafory również na te słowa skutkowałoby niedorzecznością w kontekście starożytnego społeczeństwa patriarchalnego. Po drugie, dziewictwo oblubienicy jest wysławiane przez jej interlokutora $\mathrm{w}$ dalszych częściach tekstu (Pnp 4,I2; 7,I4). Trzeba więc ponownie podkreślić, że obrazy Pnp I,5-6 nie są same w sobie metaforyczne. 


\section{Żydowska i chrześcijańska recepcja Pnp 1,5-6}

Przechodząc teraz do historii recepcji Pnp 1,5-6, czyli tego, jak rozumieli go późniejsi interpretatorzy, trzeba poczynić kilka uwag wstępnych. Starożytni i wczesnośredniowieczni interpretatorzy Pieśni nad Pieśniami - tak żydowscy, jak i chrześcijańscy - w zdecydowanej większości odczytywali ten tekst niedosłownie, nierzadko alegorycznie bądź mistycznie. Pomimo cielesneji doczesnej wymowy tekstu, jak również braku wzmianki o Bogu ${ }^{4}$, egzegeci uznają go za wyrażający głębokie - nawet najgłębsze - prawdy religijne. Słynne jest dictum rabbiego Akiwy cytowane w Misznie

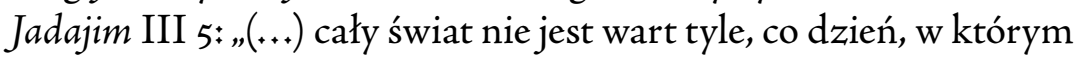
Pieśń nad Pieśniami została dana Izraelowi. Wszystkie Pisma są święte, ale Pieśń nad Pieśniami jest Świętym Świętych”. Równocześnie egzegeci zdają się pomijać milczeniem, a nawet uciekać od dosłownej warstwy tego utworu, który jest w swojej istocie przykładem poezji miłosnej. W dalszej części artykułu zostanie jednak wykazane, że nie pozostają oni głusi na głęboko zmysłowy wydźwięk Pieśni nad Pieśniami.

\section{Targum i midrasz}

Pierwsze analizie poddane zostaną żydowskie teksty rabiniczne. Są one późniejsze od interpretacji Orygenesa, która omówiona zostanie w sekcji następnej, bowiem tak targum, jak i midrasz są wczesnośredniowieczne czy też, w terminologii judaistyki, potalmudyczne, zachowując równocześnie tradycje i motywy popularne również wśród Żydów starożytnych. Przedstawione zostaną

4 Nie jest pewne, czy Bóg nie zostaje wspomniany w Pnp 8,6, którego ostatnie słowo, szal’hewetja, może oznaczać „płomień Pana” lub też „wielki płomień”; por. Barbiero, 20II, s. 464-467.

5 Tłumaczenie w oparcie o wydanie Blackmana (1955, s. 764). „Pisma” oznaczają Ketuwim, trzeci - obok Tory i Newi’ im, „Proroków” - zbiór ksiąg Biblii hebrajskiej. Święte Świętych (hebr. qodesz haqqodaszim) było zaś najświętszą częścią Świątyni Jerozolimskiej, gdzie przechowywana była Arka Przymierza, a najwyższy kapłan - i tylko on - miał wstęp jedynie w święto Jom Kipur. 
dwa teksty - targum do Pieśni nad Pieśniami, czyli jej aramejska parafraza, oraz na Szir Haszirim Rabba, czyli midrasz (rabiniczny komentarz) do tej księgi.

Zanim przytoczony zostanie tekst targumu, konieczne są dwie uwagi wstępne. Po pierwsze, targumy to parafrazy (o zróżnicowanym stopniu dowolności) hebrajskich tekstów biblijnych w spokrewnionym z nim języku aramejskim, który stał się w okresie perskim dominującym językiem Lewantu ${ }^{6}$. Po drugie, targum do Pieśni nad Pieśniami, spisany najprawdopodobniej w okresie po najeździe arabskim w VII lub VIII wieku n.e. w Palestynie (Alexander, 2003, s. 55-60), jest dość osobliwy, ponieważ nie jest zainteresowany tekstem oryginalnym per se, ale raczej traktuje go jako przyczynek do rozważań nad historią i przyszłością Izraela (Alexander, 2003, s. 13-18). W ten schemat interpretacyjny wpisane jest te $\dot{z}$ wytłumaczenie Pnp I,5-6, przytoczone poniżej in extenso:

Kiedy lud, dom Izraela, uczynił [złotego] cielca, ich twarze poczerniały jak u Kuszytów, którzy mieszkają w namiotach Kedaru. Ale kiedy nawrócili się i wybaczono im, jasność chwały ich twarzy wzrosła jak u aniołów, bowiem uczynili zasłony Przybytku i obecność Pana była wśród nich. I Mojżesz, ich mistrz, wstąpił do nieba i zaprowadził pokój pomiędzy nimi a ich królami.

I zebranie Izraela rzekło przed ludamiः „Nie gardź mną, że jestem czarniejsza od ciebie, bo postąpiłam tak, jak ty postąpiłeś, i pokłoniłam się słońcu i księżycowi. Bowiem to fałszywi prorocy spowodowali, że spadł na mnie potężny gniew Pana, to oni nauczyli mnie czcić wasze bożki i postępować według waszych praw. Ale Pana Świata, który jest moim Bogiem, nie czciłam i nie przestrzegałam jego praw i nie zachowywałam jego przykazań i nauczania”.

Na pierwszy rzut oka trudno uznać powyższy ustęp za tłumaczenie czy nawet parafrazę Pnp I,5-6, gdyż koncentruje się

6 Por. ogólne wprowadzenie do tematyki tekstów targumicznych u Wróbla (2017).

7 Tłumaczenie autora w oparciu o tekst Litkego (2019, s. 236-238). 
na zupełnie innym wydarzeniu w dziejach Izraela, a mianowicie na historii złotego cielca w Księdze Wyjścia 32. Targum przedstawia czytelnikom i czytelniczkom hagadę, tj. opowieść rabiniczną, w której bohater zbiorowy - Izrael - wyznaje skruchę za swoje bałwochwalstwo i nawraca się. Uważna lektura tekstu aramejskiego ujawnia jednak jego głębokie inspiracje tekstem Pieśni nad Pieśniami, z którego przejmuje liczne detale. Oblubienica w Pnp I,5 porównuje swoją skórę do namiotów Kedaru, zaś twarze oddanych idolatrii Izraelitów czernieją jak twarze Kuszytów (Nubijczyków) mieszkających w tych właśnie namiotach. Pnp I,5 wspomina też o zasłonach Salomona, co targum przekształca w zasłony Przybytku Mojżeszowego, czyli ruchomej świątyni Izraelitów mieszczącej Arkę Przymierza i towarzyszącej im w czasie wędrówki po pustyni. Jest to zmiana egzegetycznie uzasadniona, bowiem Biblia nigdzie nie opisuje zasłon Świątyni Salomona, ale użyte w Pnp I,5 słowo jerija jest wielokrotnie stosowane w odniesieniu do Przybytku. Bracia i ich winnica w Pnp I,6 stają się w targumie fałszywymi prorokami wiodącymi Izrael ku obcym bożkom. Egzegeta tworzy więc skomplikowaną kombinację motywów z Księgi Rodzaju i Pieśni nad Pieśniami, ale zdaje się nie tracić $z$ oczu swojego podstawowego zadania, czyli objaśnienia sensu tej drugiej księgi. Jest ona dla niego historią miłości i trwałego przymierza pomiędzy oblubieńcem, tj. Bogiem, a oblubienicą-Izraelem; Pieśń nad Pieśniami zamyka w sobie niejako i sublimuje sens całych dziejów Izraela. W ramach tego rozumienia, Pnp I,5-6, w oryginale samoopis zawstydzonej mówiącej, staje się okazją do ukazania żalu z powodu porzucenia Boga, które nabiera wagi zdrady, a następnie powrotu do niego.

Kolejna warta uwagi żydowska interpretacja Pieśni nad Pieśniami zawarta jest w midraszu Szir Haszirim Rabba, powstałego między szóstym a ósmym wiekiem n.e. (Lachs, 1965, s. 246-249; Stemberger, 20II, s. 349). Midrasze, tj. komentarze rabiniczne do ksiąg biblijnych, są zazwyczaj różnicowane na dwa podstawowe typy: halachiczne, tj. objaśniające kwestie prawa żydowskiego na podstawie tekstu biblijnego, i hagadyczne, zawierające narracje i homilie. Midrasz Szir Haszirim Rabba, będący częścią większego zbioru pt. Midrasz Rabba, obejmującego komentarze 
do Tory i pięciu megilot, jest midraszem hagadycznym, skupionym na drobiazgowym objaśnianiu tekstu Pieśni nad Pieśniami za pomocą tradycyjnej hermeneutyki żydowskiej. Ciekawą cechą tego komentarza jest fakt, że w wielu miejscach jest kompilacją fragmentów $z$ innych pism rabinicznych.

Nie sposób przytoczyć tu całości obszernego midrasza poświęconego Pnp 1,5-6, można jednak wyeksponować kilka istotnych jego wątków. Cały komentarz rozpoczyna się od stwierdzenia niemalże programowego dla żydowskiej interpretacji Pieśni nad Pieśniami:

„Czarna jestem, lecz piękna”. Jestem czarna swoimi czynami, ale piękna czynami swoich przodków. "Czarna jestem, lecz piękna”. Zgromadzenie Izraela powiedziało: „Czarna jestem przed samą sobą, lecz piękna przed moim Stwórcą". Bowiem napisano: „Czyż nie jesteście dla mnie jak synowie Kuszytów, o synowie Izraela? Wyrocznia Pana” [Am 9,7]. „Jesteście jak synowie Kuszytów” przed samymi sobą, ale ,jesteście dla mnie jak synowie Izraela wyrocznia Pana".

Autor midrasza rozpracowuje pierwsze słowa Pnp I,5 jako wyraz wstydu Izraela i niezmiennej miłości doń Boga, uzasadniając to wersetem $z$ proroctwa Amosa, które zostaje rozłożone w taki sposób, by ukazać przeciwstawienie ciemnoskórych i Bogu obojętnych Kuszytów pięknym i ukochanym Izraelitom. Midrasz następnie przedstawia długą listę wydarzeń z okresu wyjścia z Egiptu, kiedy Izraelici byli Bogu niewierni - w tym np. czczenie złotego cielca - uznając je za spełnienie słów „Czarna jestem”, i zestawia je każdorazowo z przykładem wierności Izraela z tego okresu, wiążąc je ze słowami „lecz piękna”.

Dalsza część midrasza podejmuje różnorakie wątki, m.in. do jakiego wydarzenia $z$ historii Izraela odnosić mogą się słowa „Synowie mojej matki zapłonęli gniewem wobec mnie”. Motyw nieposłuszeństwa czy uniżenia i niezważającej na nie miłości powraca jednak w rozważaniach rabinów wielokrotnie:

8 Tu i niżej tłumaczenie autora w oparciu o wydanie Dunsky'ego (I980, s. 29-35). 
Rabbi Lewi bar Chajta mówi o tym wersecie [Pnp I,5] na trzy sposoby: „Czarna jestem” przez wszystkie dni tygodnia, „lecz piękna” w szabat. „Czarna jestem” przez cały rok, „lecz piękna” w Jom Kipur. „Czarna jestem” przez dziesięć [zaginionych] plemion, „lecz piękna” przez plemiona Judy i Benjamina. „Czarna jestem” w tym świecie, „lecz piękna” w świecie przyszłym.

\section{I dalej:}

Jeśli tak będą szemrać narody świata przeciw Izraelowi i mówić: "Ten naród wymienił swoją chwałę”, bowiem powiedziano: „I zamienili swoją chwałę [na obraz wołu jedzącego trawę"; Ps 106,20], Izrael odpowie im: "Jeżeli za jeden [grzech] zostaliśmy tak skazani, to o ile bardziej wy! (...) Tak samo $z$ nami, jeżeli słońce posługi gwiazdom [tj. idolatrii] opaliło nas, wy jesteście opaleni od wyjścia $z$ łon waszych matek, bowiem już w łonach waszych matek służyliście gwiazdom".

Powyższe fragmenty uwypuklają, że Pnp I,5-6, jak i całość tekstu są rozumiane przez rabinów i autora midrasza Szir Haszirim Rabba jako alegoria stosunku między Bogiem i Izraelem, którego grzechy, przede wszystkim bałwochwalstwo, poczerniają i oczerniają go. W oczach swego Boga jest on jednak nadal piękny i utrzymuje szczególny, wybrany i umocowany w przymierzu status. Cechy fizyczne nadmieniane w tekście tracą swój dosłowny charakter, bowiem sam tekst przestaje być historią miłości dwojga ludzi - czerń i piękno stają się widomymi znamionami relacji dwojga postaci: transcendentnej (Boga) i kolektywnej (Izraela). Podobieństwa między midraszem a targumem, np. odniesienia do historii o złotym cielcu, do historii biblijnej w ogóle oraz do pogańskiego kultu ciał astralnych, nie pozwalają na ustalenie, który $z$ tych tekstów funkcjonował jako źródło dla drugiego (Alexander, 2003, s. 36, 39-4I), ale oba wskazują nad rozpowszechniony wśród Żydów tego okresu sposób interpretowania Pieśni nad Pieśniami. 


\section{Komentarz i homilie Orygenesa z Aleksandrii}

Po rozważeniu przykładów egzegezy żydowskiej dokonano analizy ustępów z dzieł egzegetycznych Orygenesa z Aleksandrii, żyjącego między I84 a 254 rokiem n.e. teologa i egzegety chrześcijańskiego, powszechnie uznawanego za najwybitniejszego przed Augustynem. Orygenes poświęcił wiele Pieśni nad Pieśniami pracy egzegetycznej i homiletycznej, której pozostałością są obszerne fragmenty jego komentarza, powstałego ok. 240 roku, i późniejszych homilii do tej księgi biblijnej (Lawson, I957, s. 4, I7). Oryginalny tekst grecki nie zachował się do naszych czasów i pozostały po nim jedynie późniejsze wyciągi w tłumaczeniach łacińskich - komentarz przełożył Rufin z Akwilei (ok. 345-4II), zaś homilie Hieronim ze Strydonu (342/347-420). Tak w komentarzu, jak i w homiliach dojrzały już intelektualnie Orygenes rozwija teologię Kościoła jako oblubienicy i Chrystusa jako oblubieńca, która staje się w czasach późniejszych dominującym chrześcijańskim sposobem odczytywania Pieśni nad Pieśniami. Oryginalność i wpływowość Orygenesowskich interpretacji potwierdza Hieronim, który we wstępie do homilii pisze: „Orygenes, który w swoich innych pismach przewyższył wszystkich, w [homiliach] do Pieśni nad Pieśniami przewyższył samego siebie”.

W drugiej księdze swojego komentarza Orygenes przystępuje do egzegezy Pnp I,5, opierając się na wcześniej sformułowanej typologii Chrystusa i Kościoła jako oblubieńca i oblubienicy. Po krótkiej parafrazie wersetu Orygenes przechodzi do interpretacji mistycznej, mającej na celu wyjaśnienie prawdziwego znaczenia czerni i piękna oblubienicy, a z której warto przytoczyć dłuższy ustęp:

Ta oblubienica, która mówi, stanowi obraz Kościoła zebranego „spośród pogan” [Dz 15,I4]; „,órki Jerozolimy” zaś te, do których się zwraca, (...) to "córki Jerozolimy” ziemskiej, które, widząc Kościół "spośród pogan”, który to nie może przypisać sobie Abrahama, Izaaka i Jakuba przez niegodziwość swego rodu, jako że „opuścił

9 Cytaty $z$ dzieł Orygenesa w tłumaczeniu autora artykułu według wydania Baehrensa (1925). 
lud swój i dom ojca" [Ps 45,II] swojego i przyszedł do Chrystusa, na swój sposób gardzą nią i oczerniają ze względu na niegodność jej pochodzenia.

Ponieważ oblubienica zdaje sobie sprawę, że córki pierwszego ludu oskarżają i przez to nazywają ją „czarną”, gdyż nie posiada blasku mądrości ojców, odpowiada im, mówiąc:

Zatem czarna jestem, o córki Jerozolimy, ponieważ nie pochodzę ze szczepu światłych mężów ani nie przyjęłam oświecenia prawa Mojżesza, ale mam w sobie swoje własne piękno. Mam bowiem w sobie tę rzecz pierwszą, która stworzona została we mnie „na obraz Boga" [Rdz 1,27] i teraz, przychodząc do Słowa Bożego, otrzymałam swój wygląd.

Interpretacja Pnp I,5 w myśli Orygenesa skupia się na relacji nie między Bogiem a Kościołem, ale między Kościołem a Izraelem, który jest rzekomo dostrzegalny w postaci druhen oblubienicy. Dokonuje się tutaj - z perspektywy historii chrześcijaństwa i judaizmu - fundamentalna substytucja Kościoła, złożonego przede wszystkim $z$ osób pochodzenia pogańskiego czy też nieżydowskiego, w miejsce Salomonowej oblubienicy. Egzegeta czyni więc Kościół obiektem niezmiennej i głębokiej miłości Boga. Czerń mówiącej oznacza dla Orygenesa jej niskie pochodzenie, brak związku z patriarchami starego przymierza i znajomości prawa, co stanowi przedmiot rzekomych drwin druhen ${ }^{\text {10 }}$. Opierając się na słowach „lecz piękna” z Pnp I,5, Orygenes formułuje obronę przed zarzutami żydowskimi - piękno oblubienicy jest równocześnie przyrodzone jako wynik bycia stworzoną przez Boga i nadane poprzez przyjęcie Słowa Bożego. W dalszej części komentarza Orygenes rozwija wątek niskiego i pogańskiego pochodzenia oblubienicy, przytaczając liczne ustępy biblijne dotyczące

Io Paralele z egzegezą żydowską, przede wszystkim z midraszowymi sformułowaniami o zasługach przodków przytaczanymi wyżej, wskazują, że Orygenes mógł znać i odpowiadać na żydowskie interpretacje Pieśni nad Pieśniami, których późniejsze formy zostały utrwalone w targumie i midraszu; por. Scholem, I965, s. 36-42; Kimelman, I980. 
Etiopii, skąd oblubienica miałaby pochodzić - w starożytności osoby o śniadej czy ciemnej cerze były stereotypowo kojarzone $z$ Etiopią, Nubią lub południową Arabią - chcąc potwierdzić tym samym, że nawet osoba zewnętrznie naznaczona czernią może stać się oblubienicą-Kościołem.

W komentarzu do wersetu szóstego Orygenes, opierając się na Pnp 8,5a w tłumaczeniu Septuagintyः „Kim jest ta, która podchodzi wybielała?", koncentruje się na wykazaniu, że czerń skóry oblubienicy jest tymczasowa. Tłumaczy się ona z niej następująco:

Nie sądźcie, o „córki Jerozolimy”, że czerń, którą widzicie na mojej twarzy, jest naturalna, ale wiedzcie, że to przez to, że słońce spojrzało na mnie krzywo. „Słońce sprawiedliwości” [Ml 3,23], które znalazło mnie niestojącą prosto, samo nie skierowało na mnie prosto światła swoich promieni.

Ja bowiem jestem ludem pogan, który nie spojrzał z początku na „słońce sprawiedliwości” i nie „stanął przed Panem” [Łk 2I,36]. I oto ono też nie spojrzało na mnie inaczej jak krzywo i nie stanęło przy mnie, lecz mnie pominęło. (...)

A więc ta czerń, którą we mnie potępiacie, jest we mnie, „bowiem słońce spojrzało na mnie krzywo" z powodu mojej niewiary i nieposłuszeństwa.

Rozważając dalszą część Pnp I,6, Orygenes - w przeciwieństwie do autorów rabinicznych, którzy w opiece nad cudzą winnicą widzieli metaforę idolatrii - uznaje porzucenie przez oblubienicę jej własnej uprawy za oznakę odejścia od pogańskich zwyczajów na rzecz posługi dla tych, którzy pochodzą z „niebiańskiej Jerozolimy", jak interpretuje słowa o matce oblubienicy Orygenes, inspirując się słowami Pawła w Ga 4,26.

W pierwszej homilii do Pieśni nad Pieśniami Orygenes wykłada Pnp 1,5-6 dla słuchających go wiernych, kondensując wnioski i spostrzeżenia przedstawione wcześniej w swoim komentarzu. Rozpoczyna od podkreślenia faktu, że oblubienica jest równocześnie czarna i piękna, uznając to za znamię trwającego nawrócenia: 
Odbyła pokutę za grzechy, jej wygląd jest darem nawrócenia i przeto jest opiewana jako „piękna”. Jako że nie jest jednak jeszcze oczyszczona ze zmazy wszystkich grzechów ani obmyta w zbawieniu, nazwana jest „czarną”, ale nie pozostaje w tej barwie - staje się zarazem jasna. (...) Zrozumieliśmy więc, w jaki sposób oblubienica jest i „czarna”, i „piękna”.

W dalszej części wykładu homiletycznego powracają wątki opracowane w większych szczegółach w komentarzu: biblijne odniesienia do Etiopii, opalenizna jako przemijająca oznaka pogańskiego życia, opieka nad winnicą braci jako dzieło głoszenia ewangelii. Orygenes wyraża też bardzo dosadnie, że to Kościół a nie Izrael - jest teraz obiektem Bożej miłości: „I ty, wyznawco, skieruj swe słowa do «córek Jerozolimy» i powiedz: «Mnie bardziej kocha oblubieniec i bardziej mu się podobam niż wy, które liczne jesteście, córki Jerozolimy. Wy stoicie na zewnątrz i widzicie, jak oblubienica wchodzi do komnaty»".

Orygenes w swoim komentarzu i homiliach do Pieśni nad Pieśniami traktuje czerń i piękno oblubienicy na dwa podstawowe sposoby: z jednej strony w sposób typologiczny, jako opis Kościoła wywodzącego się spośród pogan, ale przyjmującego Chrystusa, a z drugiej strony alegorycznie czy wręcz mistycznie, jako stopniowe przechodzenie $z$ grzechu w kierunku chrześcijańskiej doskonałości. Nawet kiedy aleksandryjski egzegeta wzmiankuje ludy afrykańskie i arabskie o rzeczywiście śniadej karnacji lub czarnej skórze, nie jest on zainteresowany ich fizycznością czy związkiem $z$ historycznym kontekstem Pieśni nad Pieśniami, ale jedynie ich nawróceniem. Niedosłowność jego lektury jest więc zamierzona, przemyślana i daleko idąca.

\section{Podsumowanie}

Wrócić teraz trzeba do pojęcia metafory ucieleśnionej. Tak rabini w targumie i midraszu, jak i Orygenes w komentarzu i homiliach, wiążą zjawiska percepcyjnie dostępne, tj. kolor czarny i piękny wygląd, z szeroką domeną pojęć abstrakcyjnych nacechowanych 
pejoratywnie, przede wszystkim niewiedzą, niskim stanem, grzechem i nieposłuszeństwem. Źródła żydowskie odczytują czerń w Pnp 1,5-6 jako metaforę tego, że Izrael grzeszył przeciwko Bogu i jest we własnych oczach niegodny, ale że jest też niezmiennie obiektem Bożej miłości i łaski. Orygenes widzi tę barwę jako znamię tego, że Kościół wywodzi się z ludów pogańskich nieznających prawa Mojżeszowego, jak również jego grzesznej, acz przemijającej przeszłości.

Nie można mieć naturalnie pewności co do tego, czy metafora czerni wywoływała w umysłach rabinów i Orygenesa rzeczywiste doznania sensoryczne. Ich teksty egzegetyczne są jednak wystarczająco przesycone obrazami - wzmiankami o czerni (zwraca uwagę repetycja słów „czarna” i „piękna” w midraszu do Pnp 1,5), opisami namiotów Kedaru, zasłon Przybytku i opalenizny - aby stwierdzić, że chcieli oni, aby ich odbiorcy nie tylko rozumieli czerń jako grzech czy nieoświecenie, ale doświadczali tego koloru w sposób zmysłowy. Pieśń nad Pieśniami dzięki swojej cielesności staje się doskonałym teologicznym polem dla narracji o rzeczach wysoce abstrakcyjnych, jak przyczyny grzechu czy miejsce danej wspólnoty w historii zbawienia - a wręcz sporu o nie. Zmysłowość tekstu biblijnego daje komentatorom szansę na dobitne wyrażenie najgłębszych dla nich prawd, które byłyby trudno uchwytne, gdyby nie były dostępne właśnie poprzez metaforę. Odbiorcy tekstu są prowadzeni od wyobrażenia sobie koloru czarnego i wyglądu oblubienicy do głębszego, może nawet najgłębszego znaczenia jej fizyczności.

$\mathrm{Na} z a k o n ́ c z e n i e$ warto przytoczyć słowa samego Orygenesa $z$ trzeciej księgi jego komentarza, które zaskakująco współbrzmią ze rozważaniami współczesnych badaczy metafor. Są one dowodem na to, że jakkolwiek współczesna refleksja kognitywistyczna nad językiem jest pomocna w studiach nad starożytnymi tekstami o charakterze religijnym, to teksty te same nierzadko ukazują wage metafor w procesach poznawczych:

[J]est niemożliwym dla człowieka żyjącego w ciele pojąć coś z rzeczy tajemnych i niewidzialnych bez powzięcia jakiegoś obrazu i podo- 
bieństwa z rzeczy widzialnych (...). A więc, jak to powiedzieliśmy wcześniej, wszystkie rzeczy widzialne mogą zostać odniesione do niewidzialnych, cielesne do bezcielesnych, a widome do tajemnych.

\section{Bibliografia}

Alexander, P.S. (red.) (2003). The Targum of Canticles. London: T\&T Clark. Baehrens, W.A. (red.) (1925). Origenes Werke. Achter Band. Homilien zum Samuel I, zum Hohelied und zu den Propheten. Kommentar zum Hohelied. Leipzig: J.C. Hinrichs.

Barbiero, G. (2011). Song of Songs. A Close Reading. Leiden-Boston: Brill. DOI: 10.1163/ej.9789004203259.i-542.

Barsalou, L.W. (1999). Perceptual Symbol Systems. Behavioral and Brain Sciences, 22(4), s. 577-660. DOI: 10.1017/Sor40525X99002149.

Blackman, P. (red.) (1955). Mishnayoth. Volume VI: Order Taharoth. London: Mishna Press (L.M. Schoenfeld).

Casasanto, D., Gijssels, T. (2015). What Makes a Metaphor an Embodied Metaphor? Linguistics Vanguard, 1(I), s. 327-337. DOI: 10.1515/ lingvan-2014-I0I5.

Dobbs-Allsopp, F.W. (2006). "I am Black and Beautiful". The Song, Cixous and Écriture Féminine. W: L. Day, C. Pressler (red.). Engaging the Bible in a Gendered World: An Introduction to Feminist Biblical Interpretation in Honor of Katherine Doob Sakenfeld (s. I28-140). Louiseville-London: Westminster John Knox Press.

Dunsky, S. (red.) (1980). Midrasz Rabba Szir Haszirim. Midrasz Hazita. Jerusalem: Dwir.

Fishbane, M. (2015). The JPS Bible Commentary: Song of Songs. Philadelphia: The Jewish Publication Society. DOI: I0.2307/j.cttId989qb. Garbini, G. (1992). Cantico dei cantici. Brescia: Paideia.

Gault, B.P. (2019). Body as Landscape, Love as Intoxication: Conceptual Metaphors in the Song of Songs. Atlanta: Society of Biblical Literature Press.

Geeraerts, D. (2009). Theories of Lexical Semantics. Oxford: Oxford University Press. DOI: 10.1093/acprof:0so/9780198700302.00I.000I. Gibbs, R.W. (2017). Metaphor Wars: Conceptual Metaphors in Human Life. Cambridge: Cambridge University Press. DOI: 10.10I7/9781107762350. 
Grady, J.E. (1999). A Typology of Motivation for Conceptual Metaphor: Correlation vs. Resemblance. W: R.W. Gibbs, G.J. Steen (red.). Metaphor in Cognitive Linguistics: Selected papers from the 5th International Cognitive Linguistics Conference (s. 79-100). Amsterdam: John Benjamins Publishing Company.

Hogan, K.M. (20II). Mother Earth as a Conceptual Metaphor in 4 Ezra. The Catholic Biblical Quarterly, 73(I), s. 72-91.

Hostetter, E.C. (1996). Mistranslation in Cant 1:5. Andrews University Seminary Studies, 34(I), s. 35-36.

Howe, B.G. (2006). Because You Bear This Name: Conceptual Metaphor and the Moral Meaning of 1 Peter. Leiden: Brill. DOI: Io.II63/ ej.9789004I50959.i-398.

Jindo, J.Y. (2010). Biblical Metaphor Reconsidered: A Cognitive Approach to Poetic Prophecy in Jeremiah 1-24. Winona Lake: Eisenbrauns. DOI: 10.1163/9789004368187.

Johnson, M. (1987). The Body in the Mind: The Bodily Basis of Meaning, Imagination, and Reason. Chicago: University of Chicago Press.

Kimelman, R. (1980). Rabbi Yohanan and Origen on the Song of Songs: A Third-Century Jewish-Christian Disputation. Harvard Theological Review, 73(3-4), s. 567-595. DOI: 10.10I7/Sool7816000002327.

Lachs, S.T. (I965). Prolegomena to Canticles Rabba. Jewish Quarterly Review, 55(3), s. 235-255. DOI: 10.2307/1453719.

Lakoff, G., Johnson, M. (1980). Metaphors We Live By. Chicago: University of Chicago Press.

Lawson, R.P. (1957). Introduction. W: Idem (red.). Origen: Song of Songs - Commentary and Homilies (s. 3-20). London: Longmans, Green and Co.

Litke, A.W. (2019). Targum Song of Songs and Late Jewish Literary Aramaic: Language, Lexicon, Text, and Translation. Leiden-Boston: Brill. DOI: I0.II63/9789004393752.

Miller, R.D. (2012). The Song of Songs: A Plea for an Aesthetic Reading. Sacra Scripta, 10(2), S. II3-II9.

Murphy, R.E. (1990). The Song of Songs: A Commentary on the Book of Canticles or The Song of Songs. Minneapolis: Fortress Press.

Ogden Bellis, A. (202I). I Am Burnt but Beautiful: Translating Song I:5a. Journal of Biblical Literature, 140(I), s. 9I-III. DOI: I0.I5699/ jbl.I40I.202I.5. 
Pope, M.H. (I977). Song of Songs: A New Translation with Introduction and Commentary. New Haven: Yale University Press.

Scholem, G.G. (1965). Jewish Gnosticism, Merkabah Mysticism, and Talmudic Tradition. New York: The Jewish Theological Seminary of America.

Stemberger, G. (20II). Einleitung in Talmud und Midrasch. Monachium: C.H. Beck.

Tilford, N.L. (2017). Sensing World, Sensing Wisdom: The Cognitive Foundations of Biblical Metaphor. Atlanta: Society of Biblical Literature Press. DOI: 10.2307/j.cttIpovjz8.

Wabyanga, R.K. (2015). Song of Songs I:5-7: The Africana Reading. Journal of Theology for Southern Africa, 150, s. I28-I47.

Wronka, S. (2004). Transliteracja i transkrypcja alfabetu hebrajskiego. Ruch Biblijny i Liturgiczny, 57(I), s. 45-58.

Wróbel, M.S. (20I7). Wprowadzenie do Biblii aramejskiej. Lublin: Gaudium.

Zakovitch, Y. (2004). Das Hohelied. Freiburg im Breisgau: Herder. 